\title{
Various dosages of active powder of cassava improved sustainability of physical and chemical characteristics of Vertisol and Alfisol on dryland farming system
}

\author{
IN P. SOETEDJO \\ Department of Agrotechnology, Faculty of Agriculture, Universitas Nusa Cendana. Jl. Adisucipto, Penfui, Kupang 85001, East Nusa Tenggara, \\ Indonesia. Tel./fax.: +62-380-881085, `email: prijo_2005@yahoo.com
}

Manuscript received: 12 November 2018. Revision accepted: 23 May 2019.

\begin{abstract}
Soetedjo IP. 2019. Various dosages of active powder of cassava improved sustainability of physical and chemical characteristics of Vertisol and Alfisol on dryland farming system. Trop Drylands 3: 29-33. Vertisol and Alfisol are two types of dominant soil in dryland farming systems. Both soils generally have a low content of some nutrients such as N, P, K, C organic, and are dominated by clay, high water saturation, and prone to $\mathrm{Al}, \mathrm{Fe}$, and $\mathrm{Mn}$ poisonings. An innovative product called active powder may improve soil microbiology activity and physical characteristics of soil, which might then improve the availability of soil nutrients. Research had been done to know the effect of various dosages of active powder to enhance the physical and chemical characteristics of Vertisol and Alfisol in dryland farming systems in Kupang, East Nusa Tenggara, Indonesia. The research was a factorial treatment design laid out in a Randomized Complete Block Design with four replicates for each treatment. The treatments employed were two types of soil (Vertisol and Alfisol) and various dosages of active powder (0, 100, 200, and $\left.300 \mathrm{~g} \mathrm{ha}^{-1}\right)$. Parameters observed were subjected to ANOVA and was followed by a Least Significant Different Test at 0.05 level. Results of the research showed that dosage of active powder of $300 \mathrm{~g} \mathrm{ha}^{-1}$ was able to improve the number colony of soil bacteria, soil porosity, soil bulk density, total N, P availability, and $\mathrm{K}$ availability. Generally, the physical and chemical characteristic of Vertisol was better improved than Alfisol. The yield of mungbean was significantly affected by the dosage of the active powder of 200-300 $\mathrm{g} \mathrm{ha}^{-1}$ in which yield of mungbean grown at Vertisol was higher than that at Alfisol.
\end{abstract}

Keywords: Alfisol, dosage, active powder of cassava, physical and chemical characteristic of soil, vertisol

\section{INTRODUCTION}

Alfisol and Vertisol are two types of soil that dominantly occurred in dryland areas such as in East Nusa Tenggara, Indonesia. Alfisol has low content of nutrients such as $\mathrm{N}, \mathrm{P}, \mathrm{K}, \mathrm{C}$ organic, $\mathrm{Mo}, \mathrm{Mg}$, and poisoning levels of $\mathrm{Al}, \mathrm{Fe}$, and $\mathrm{Mn}$. Moreover, Alfisol has medium to high bulk density, less to medium soil permeability, low water soil resistance, high sensitivity to erosion, and low content of soil microbiology. Similarly, Vertisol has a low content of some nutrients such as N, P, K, C organic, dominated by clay, and high water saturation (Hardjowigeno 2015; Serangmo 2015). Those characteristics result in low soil quality, limiting the capabilities of the soil in supporting growth and yield of crops. Numerous ways have been practiced to improve the capabilities of Vertisol and Alfisol, such as applying organic and organic fertilizers. However, several studies showed that those practices resulted in the increase of soil compaction, and increasing of soil microbiology dormancy (Debosz, et al. 2001; Abebe 2001; Esmaeilzadeh and Ahangar 2014).

Soil microbiology elements are needed to improve physical soil characteristics and improve some soil nutrient availability. Previous studies showed that organic fertilizer could improve the availability of soil microorganisms and the availability of nitrogen, phosphorus, and potassium (Doran and Zeiss 2000; Debosz et al. 2001; Abu-Zahra and
Tahboub 2008). However, it needs a great quantity of organic fertilizer, about $10-20 \mathrm{t} \mathrm{ha}^{-1}$. This quantity is hardly fulfilled in dryland farming system practices, which is generally limited in sources of organic matter and manpower. Therefore, it is necessary to find innovative technologies that could minimize the use of organic sources, but could improve the physical and chemical characteristics of soil.

The active powder is one of innovative products that are available to improve soil microbiology activities, which then improve the availability of some soil nutrients. Physically, the active powder may be able to maximally increase the use of gamma radiation to increase the number of oxygen in the soil. Gamma radiation can intercept into $50 \mathrm{~cm}$ soil depth, which increases the degradation of $\mathrm{H}_{2} \mathrm{O}$ becomes hydrogen $\left(\mathrm{H}_{2}\right)$ and oxygen $\left(\mathrm{O}_{2}\right)$. Increased soil oxygen levels will increase the activity and biomass of soil microorganisms, which may stimulate the improvement of soil structure, soil aeration, exchange capacity of anions and cations, and nutrient availability. These positive effects, however, will strongly depend on soil type, the dosage and time of application, and plant growth, which are mainly due to various types of soil that have different physical and chemical characteristics as reported by Esmaeilzadeh and Ahangar (2014) and Hardjowigeno (2015). This research aimed to know the effect of various 
dosages of active powder of cassava on enhancing the physical and chemical characteristics of Vertisol and Alfisol in dryland farming systems in Kupang, East Nusa Tenggara, Indonesia.

\section{MATERIALS AND METHODS}

\section{Research location and materials}

The present research was conducted at Naibonat Village (dominated by Vertisol) and Matani Village (dominated by Alfisol), Kupang District, East Nusa Tenggara Province, Indonesia from May to October 2017. Materials used in the research were active powder of cassava and mungbean plants.

\section{Research design}

A factorial experimental design was employed, laid out in a Randomized Complete Block Design with four replications. The assigned treatments consisted of two soil types (Vertisol and Alfisol) as the first factor and dosages of active powder $\left(0,100,200300 \mathrm{~g} \mathrm{ha}^{-1}\right)$ as the second factor. The active powder was applied during planting.

\section{Experimental procedures}

Active powder of cassava was prepared two days before application into the soil. All active powder of cassava was mixed with $2 \mathrm{~kg} \mathrm{ha}^{-1}$ of wheat flour and thereafter mixed with 4 liters of water. Mungbean was grown on planting plot of $2 \mathrm{~m} \times 6 \mathrm{~m}$ with planting space of $20 \mathrm{~cm} \times 40 \mathrm{~cm}$.

Three soil samples were collected before planting at 0 $20 \mathrm{~cm}$ soil depth from each replicate area by using an auger and were mixed to form a composite sample for each treatment. Each soil sample was mixed, then four replications were taken for measurements and analysis and the average readings were recorded. Besides, at the end of the experiment soil samples were collected in the same manner, as before planting, but replicates of each treatment were not mixed with each other, and analysis was done on the four replicate samples for each treatment, then average readings were recorded.

\section{Observation and data analysis}

Observed parameters included the number of the colony of soil bacteria, nutrients content (Nitrogen, Phosphorus, Potassium, C organic), and yield of mungbean. Soil chemical characteristic and number of colony soil bacteria of sample soil were analyzed before planting and after harvest. Total nitrogen $(\mathrm{N})$ was determined by using a micro Kjeldahl method (Bremner and Mulvaney 1982). Available phosphorus (P) was extracted by $0.5 \mathrm{~N}$ NaHCO with $\mathrm{pH}$ of 8.5 with Spectrophotometer (Olsen and Sommers 1982). Available potassium (K) was extracted by $1 \mathrm{~N}$ ammonium acetate determined by Flame Photometer (Knudsen Peterson and Pratt 1982).

The yield of mungbean was observed at the end of the research by weighting dry seeds harvested per plant and per plot. The treatment means were separated by using the Least Significant Difference at 5\% significant level.

\section{RESULTS AND DISCUSSION}

\section{Soil bacteria colony}

Result of this research showed that increasing the application dosage of active powder up to $300 \mathrm{~g} \mathrm{ha}^{-1}$ resulted in an increase in the number of soil bacteria colonies (Table 1) on both soil types (Vertisol and Alfisol). This is mainly because those soils have a clay content, low soil porosity and high bulk density. These conditions resulted in low content of Oxygen that soil microorganism activities highly require it. By the application of active powder up to $300 \mathrm{~g} \mathrm{ha}^{-1}$, the available oxygen becomes higher, which may able to increase the number and activities of soil microorganisms. This will then result in improved soil porosity, improved soil aeration, decreases in bulk density, and improvement of cation exchangeable capacity. Several studies reported that the availability of soil microorganisms depends strongly on soil microclimatic conditions such as $\mathrm{pH}$, aeration, energy sources and soil management (Hassink 1994; Papadopoulos et al. 2006; Jangid 2008).

Moreover, the research showed that number of bacteria colonies was higher at Vertisol than Alfisol (Table 2). This is mainly due to the percentage of porosities on Vertisol was relatively higher than Alfisol at the various dosages of active powder applications. This significantly affected an increase of oxygen level and increase the source of energy required by soil microorganism activities. Hassink (1994); Papadoulos (2006), and Soetedjo (2018) reported that availability of nutrients, well aeration and drainage, better source of energy (solar radiation and organic matter) are several factors that should be taken into account to improve soil microorganism growth and development.

Table 1. The effect of various dosages of active powder application on the number of soil bacteria

\begin{tabular}{lccccc}
\hline $\begin{array}{c}\text { Active } \\
\text { powder } \\
\text { dosage }(\mathbf{g} \\
\left.\text { ha }^{-1}\right)\end{array}$ & \begin{tabular}{c} 
Number of soil bacteria colony \\
\cline { 2 - 5 }
\end{tabular} & $\begin{array}{c}\text { Before active } \\
\text { powder } \\
\text { application }\end{array}$ & $\begin{array}{c}\text { After active } \\
\text { powder } \\
\text { application }\end{array}$ & $\begin{array}{c}\text { Changeable } \\
\text { number of } \\
\text { soil bacteria } \\
\text { colony }\end{array}$ \\
\hline 0 & 236.5 & 233.50 & a & 3 & a \\
100 & 236.5 & 271.37 & b & 34.87 & b \\
200 & 236.5 & 285.25 & bc & 48.75 & bc \\
300 & 236.5 & 292.87 & c & 53.37 & c \\
LSD 5\% & & 15.23 & & 15.23 & \\
\hline
\end{tabular}

Note: Numbers followed by the same letter at the same column means not significantly different at LSD 5\% level

Table 2. Number of soil bacteria at different soil types as affected by various dosages of application

\begin{tabular}{lccc}
\hline Soil type & \multicolumn{2}{c}{$\begin{array}{c}\text { Number of soil bacteria } \\
\text { colony }\end{array}$} & $\begin{array}{c}\text { Changeable } \\
\text { of Number of } \\
\text { soil bacteria } \\
\text { colony }\end{array}$ \\
\cline { 2 - 3 } & $\begin{array}{c}\text { Before } \\
\text { application }\end{array}$ & $\begin{array}{c}\text { After } \\
\text { application }\end{array}$ & $25.68 \mathrm{a}$ \\
Vertisol & 261.5 & $277.63 \mathrm{~b}$ & $52.38 \mathrm{~b}$ \\
Alfisol & 211.5 & $263.88 \mathrm{a}$ & 10.77 \\
LSD 5\% & & 10.77 & \\
\hline
\end{tabular}

Note: Numbers followed by the same letter at the same column means not significantly different at LSD 5\% level 


\section{Soil porosity}

Result of the present research showed that active powder application significantly affected soil porosity. Applications of 100 - $300 \mathrm{~g} \mathrm{ha}^{-1}$ active powder resulted in increase soil porosity of Vertisol and Alfisol as compared to no application of active powder (Table 3). These results showed that active powder can improve oxygen level on the soil, which resulted in increasing soil microorganism activities to improve soil porosities, soil aeration, and decrease bulk density (Papadopoulus et al. 2006; Jangid et al. 2008; Soetedjo 2018). Moreover, improvement of soil porosities of Vertisol was higher than soil porosities of Alfisol. Some studies by Granatstein et al. (1987), Hassink (1994), and Soetedjo (2008) reported that activities and biomass of soil microorganisms significantly increased soil physical properties of low clay content than high clay content (Table 4).

\section{Total nitrogen content}

There was no interaction effect of the application dosage of active powder and type of soil on Nitrogen content. However, the single factor dosage and type of soil significantly affected Nitrogen content. LSD test at level $5 \%$ showed that active powder application up to $300 \mathrm{~g} \mathrm{ha}^{-1}$ resulted in an increase in Nitrogen content of both types of soil, where the rise of Nitrogen content on Vertisol was significantly higher than that on Alfisol (Table 5).

An increase in nitrogen content at $300 \mathrm{~g} \mathrm{ha}^{-1}$ of active powder application is mainly due to the increased number of microorganisms that resulted in improvement of soil micro-bacteria activities, improvement of soil porosity, decreasing in soil colloid and improvement of exchangeable cation capacity. Several studies by Granatstein et al. (1987), Wild. (1993), and Beja et al. (2015) reported that increase in number and activities of soil microorganisms as result of various soil management improved the availability of some nutrients ( $\mathrm{N}, \mathrm{P}$, and $\mathrm{K}$ ). Improvement of Vertisol is much better than Alfisol that this could be related to the physical characteristic of Vertisol, which is better in supporting gamma radiation interception into the deeper part of the soil resulted in increased number of soil microorganisms on the soil (Serangmo 2015).

\section{Available phosphorus}

The ANOVA result revealed a significant interaction effect of active powder dosage and type of soil on available phosphorus. LSD post hoc test showed that all dosages of the active powder application on Alfisol resulted in higher content of available phosphorus as compared to that of Vertisol (Table 6). This is mainly because a higher Nitrogen content on Vertisol suppressed the amount of phosphorus in the Vertisol. Meanwhile, both soil types had a high content of available Phosphorus at $300 \mathrm{~g} \mathrm{ha}^{-1}$ of active powder application. These results showed that there is significant correlation between improvement of the availability of some nutrients with increased number of soil microorganisms, and improved of porosities soil aeration (Hassink 1994; Papadoulos 2006).
Table 3. The effect of various dosages of active powder application on soil porosity

\begin{tabular}{|c|c|c|c|}
\hline \multirow{2}{*}{$\begin{array}{l}\text { Active powder } \\
\text { Dosage }\left(\mathrm{g} \mathrm{ha}^{-1}\right)\end{array}$} & \multicolumn{2}{|c|}{$\begin{array}{l}\text { Soil porosity affected by } \\
\text { active powder application }\end{array}$} & \multirow{2}{*}{$\begin{array}{c}\text { Changeable of } \\
\text { soil porosity }\end{array}$} \\
\hline & Before & $\begin{array}{c}\text { After } \\
\text { application }\end{array}$ & \\
\hline 0 & 59.65 & $58.81 \quad \mathrm{a}$ & $-0.84 \quad \mathrm{a}$ \\
\hline 100 & 59.65 & $62.97 \quad b$ & $3.32 \mathrm{~b}$ \\
\hline 200 & 59.65 & $63.06 \mathrm{~b}$ & $3.41 \quad b$ \\
\hline 300 & 59.65 & $64.97 \quad b$ & $5.32 \mathrm{~b}$ \\
\hline LSD $5 \%$ & & 3.39 & 3.39 \\
\hline
\end{tabular}

Note: Numbers followed by the same letter at the same column means not significantly different at LSD 5\% level

Table 4. Soil porosity levels at different soil types affected by various dosage applications

\begin{tabular}{|c|c|c|c|}
\hline \multirow[t]{2}{*}{ Soil type } & \multicolumn{2}{|c|}{$\begin{array}{c}\text { Soil porosity affected by active } \\
\text { powder application }\end{array}$} & \multirow{2}{*}{$\begin{array}{c}\text { Changeable } \\
\text { of soil } \\
\text { porosity }\end{array}$} \\
\hline & Before & After application & \\
\hline Vertisol & 55.01 & $60.73 \mathrm{a}$ & $5.74 \mathrm{~b}$ \\
\hline Alfisol & 64.3 & $64.15 \mathrm{~b}$ & $-0.14 \mathrm{a}$ \\
\hline LSD 5\% & & 2.40 & 2.40 \\
\hline
\end{tabular}

Note: Numbers followed by the same letter at the same column means not significantly different at LSD 5\% level

Table 5. The effect of the single factor active powder application and type of soil ton total nitrogen content (\%)

\begin{tabular}{lcccc}
\hline $\begin{array}{c}\text { Active } \\
\text { powder } \\
\text { dosage (g } \\
\text { ha-1) }\end{array}$ & $\begin{array}{c}\text { Before } \\
\text { application }\end{array}$ & $\begin{array}{c}\text { After } \\
\text { application }\end{array}$ & $\begin{array}{c}\text { Changeable of } \\
\text { nitrogen content }\end{array}$ \\
\hline 0 & 0.067 & $0.57 \quad \mathrm{a}$ & $0.51 \mathrm{a}$ \\
100 & 0.067 & $0.65 \mathrm{bc}$ & $0.58 \mathrm{ab}$ \\
200 & 0.067 & $0.66 \mathrm{c}$ & $0.59 \mathrm{~b}$ \\
300 & 0.067 & $0.71 \mathrm{c}$ & $0.64 \mathrm{~b}$ \\
LSD 5\% & & 0.07 & 0.08 \\
Vertisol & 0.067 & $0.81 \mathrm{~b}$ & $0.74 \mathrm{~b}$ \\
Alfisol & 0.067 & $0.49 \mathrm{a}$ & $0.42 \mathrm{a}$ \\
LSD 5\% & & 0.05 & 0.05 \\
\hline
\end{tabular}

Note: Numbers followed by the same letter at the same column at the different single factor of active powder dosage and soil type means not significantly different at LSD 5\% level.

Table 6. The effect of interaction between the dosage of active powder application and type of soil on available phosphorus content (ppm)

\begin{tabular}{|c|c|c|c|c|}
\hline $\begin{array}{l}\text { Type of soil/ } \\
\text { active powder } \\
\text { dosage (g ha-1 }\end{array}$ & 300 & 200 & 100 & 0 \\
\hline Vertisol & $\begin{array}{c}16.0975 \mathrm{~b} \\
\mathrm{~A}\end{array}$ & $\begin{array}{cc}15.88 & a b \\
A & \end{array}$ & $\begin{array}{c}15.4225 \\
\mathrm{~A}\end{array}$ & $\begin{array}{cc}14.81 & \mathrm{a} \\
\mathrm{A} & \end{array}$ \\
\hline Alfisol & $\begin{array}{c}22.7175 \quad b \\
B\end{array}$ & $\begin{array}{c}21.64 \quad a b \\
B\end{array}$ & $\begin{array}{c}20.3875 \mathrm{ab} \\
\mathrm{B}\end{array}$ & $\begin{array}{l}\text { 19.427: a } \\
\text { B }\end{array}$ \\
\hline
\end{tabular}

Note: Numbers followed by the same small letter at the same row and capital letter at the same column means not significantly different at 5\% LSD level. 


\section{Potassium content}

Result of the research showed no significant interaction effect of dosage of active powder application and type of soil on Potassium content. However, the single factor treatments affected the Potassium content of the soil. The application of 200-300 $\mathrm{g} \mathrm{ha}^{-1}$ of active powder significantly increased the Potassium content of both soil types; meanwhile, the Potassium content of Vertisol was higher than Alfisol (Table 7). All the results showed that improvement of the physical characteristic of the soil directly affected the nutrient content of the soil. A better increase in soil porosity resulted in increased number of soil microorganism and their activities, which stimulate increase in cation expandable capacity and availability of nutrients (Doran and Zeiss 2000; Habig and Swanepoel 2015.

\section{C organic content}

Result of the research showed no significant interaction effect of active powder and soil types on $\mathrm{C}$ organic content. However, the single factor soil type significantly affected $\mathrm{C}$ organic content. $\mathrm{C}$ organic content of Alfisol was higher than Vertisol that is mainly because Vertisol has a higher clay textured soil than Alfisol. In addition, increase in Nitrogen content affected by powder active application could cause a decrease in $\mathrm{C}$ organic content (Table 8). Several studies showed that physical characteristics of soil (texture, structure, aeration, bulk density) and chemical characteristics of soil (Total $\mathrm{N}$ content) were closely related to $\mathrm{C}$ organic content. High clay-textured soil such as Vertisol has a low $\mathrm{C}$ organic content, and a high content of $\mathrm{N}$ on Vertisol will suppress the organic content as reported by Hessink (1994);) and Abu-Zahra and Tahboub (2008).

Table 7. The effect of single factors active powder application and type of soil on potassium content (me/100g)

\begin{tabular}{|c|c|c|c|}
\hline $\begin{array}{l}\text { Active powder } \\
\text { dosage }\left(\mathrm{g} \mathrm{ha}^{-1}\right)\end{array}$ & $\begin{array}{c}\text { Before } \\
\text { application }\end{array}$ & $\begin{array}{c}\text { After } \\
\text { application }\end{array}$ & $\begin{array}{c}\text { Exchangeable } \\
\text { of potassium } \\
\text { content }\end{array}$ \\
\hline 0 & 0.66 & $0.69 \quad \mathrm{a}$ & $0.03 \quad \mathrm{a}$ \\
\hline 100 & 0.66 & 0.99 & $0.34 \quad \mathrm{a}$ \\
\hline 200 & 0.66 & $1.07 \mathrm{bc}$ & $0.41 \quad b$ \\
\hline 300 & 0.66 & $1.16 \mathrm{c}$ & $0.50 \mathrm{~b}$ \\
\hline LSD $5 \%$ & & 0.11 & 0.11 \\
\hline Vertisol & 1.21 & $1.20 \mathrm{~b}$ & $-0.02 \mathrm{a}$ \\
\hline Alfisol & 0.11 & $0.75 \mathrm{a}$ & $0.65 \mathrm{~b}$ \\
\hline LSD 5\% & & 0.08 & 0.05 \\
\hline
\end{tabular}

Note: Numbers followed by the same letter at the same column at different single factor treatment of dosage and type of soil means not significantly different at 5\% LSD.

Table 8. The effect single factor type of soil on $\mathrm{C}$ organic content of the soil (\%) affected by active powder application

\begin{tabular}{lccc}
\hline $\begin{array}{c}\text { Type of } \\
\text { soil }\end{array}$ & $\begin{array}{c}\text { Before } \\
\text { application }\end{array}$ & $\begin{array}{c}\text { After } \\
\text { application }\end{array}$ & Exchangeable \\
\hline Vertisol & 1.26 & $0.44 \mathrm{a}$ & $-8.11 \mathrm{a}$ \\
Alfisol & 1.05 & $1.15 \mathrm{~b}$ & $0.11 \mathrm{~b}$ \\
LSD 5\% & & 0.53 & 0.56 \\
\hline
\end{tabular}

Note: Numbers followed by the same letter at the same column means not significantly different at LSD 5\% level
Table 9. The effect of single factor active powder application and type of soil on the yield of mungbean $\left(\mathrm{g} / 6 \mathrm{~m}^{2}\right)$

\begin{tabular}{lcc}
\hline $\begin{array}{c}\text { Active powder } \\
\text { dosage }\left(\mathbf{g ~ h a}^{-1}\right)\end{array}$ & $\begin{array}{c}\text { Before } \\
\text { application }\end{array}$ & $\begin{array}{c}\text { After application of active } \\
\text { powder }\end{array}$ \\
\hline 0 & 0 & $166.38 \mathrm{a}$ \\
100 & 0 & $170.50 \mathrm{ab}$ \\
200 & 0 & $201.88 \mathrm{~b}$ \\
300 & 0 & $225.38 \mathrm{~b}$ \\
LSD 5\% & & 35.19 \\
Vertisol & 0 & $247.44 \mathrm{~b}$ \\
Alfisol & 0 & $134.63 \mathrm{a}$ \\
LSD 5\% & & 24.88 \\
\hline
\end{tabular}

Note: Numbers followed by the same letter at the same column at the different single variable of dosage and type of soil means not significantly different at LSD 5\%l.

\section{Yield of mungbean}

Result of the research showed that the yield of mungbean was significantly affected by the single factor treatments of dosage application of active powder and type of soil. The application of 200-300 $\mathrm{g} \mathrm{ha}^{-1}$ active powder resulted in a higher yield of mungbean $\left(\mathrm{g} / 6 \mathrm{~m}^{2}\right)$ as compared to that of no application of active powder. Moreover, the yield of mungbean on Vertisol was higher than that of Alfisol. Higher mungbean yield on Vertisol was mainly due to the improvement of physical and chemical characteristics of the Vertisol was better than Alfisol (Table 9).

In conclusion, the application of active powder significantly improved soil physical and chemical characteristics of Vertisol and Alfisol. The application of $300 \mathrm{~g} \mathrm{ha}^{-1}$ active powder resulted in a better physical and chemicals characteristic of Vertisol as compared to Alfisol. A higher yield of mungbean $\left(225 \mathrm{~g}\right.$ per $\left.6 \mathrm{~m}^{2}\right)$ was obtained by application of $300 \mathrm{~g} \mathrm{ha}^{-1}$ active powder.

\section{REFERENCES}

Abebe G. 2001. Effect of Manure on Some Physico-chemical Properties of Calcareous Soil, Yield, and Quality of Cowpea [Vigna unguiculata (L.) Walp.] Under Greenhouse Conditions. [Thesis]. University of Jordan, Amman, Jordan.

Abu-Zahra TR, Tahboub AB. 2008. Effect of organic matter sources on chemical properties of the soil and yield of strawberry under organic farming conditions. World Appl Sci J 5 (3): 383-388.

Baziramakenga R. Simard RR, Lalande R. 200. Effect of de-inking paper sludge compost application on soil chemical and biological properties. Canadian J Soil Sci 81: 561-575. DOI: 10.4141/S00-063

Beja D, Mella WII, Soetedjo IN P. 2015. Sistem Tebas Bakar Dan Pengaruhnya Terhadap Komponen Fisik Kimia Tanah Serta Vegetasi Pada Ladang Dan Lahan Bera (Studi Kasus di Desa Pruda Kecamatan Waiblama Kabupaten Sikka Provinsi Nusa Tenggara Timur). Universitas Nusa Cendana, Kupang. [Indonesian].

Bremner JM, Mulvaney CS. 1982. Nitrogen total. Methods of Soil Analysis, Part 2, Chemical and Microbiological Properties. (2 Edn). American Society of Agronomy, Inc., Publisher, Madison, Wisconsin, USA.

Debosz K, Petersen SO, Kure LK, Ambus P. 2001. Evaluating effects of sewage sludge and household compost on soil physical, chemical and microbiological properties. Appl Soil Ecol 19: 237-248. DOI: 10.1016/S0929-1393(01)00191-3

Doran JW, Zeiss. 200. M.R. Soil health and sustainability: Managing the biotic component of soil quality. Appl. Soil Ecol. 15: 3-11. DOI: 10.1016/S0929-1393(00)00067-6 
Egelkraut TM, Kissel D, Cabrera ML. 2000. Effect of soil texture on nitrogen mineralized from cotton residues and compost. J Environ Qual 29: 1518-1522. DOI: 10.2134/jeq2000.00472425002900050019x

Esmaeilzadeh J, Ahangar AG. 2014. Influence of soil organic matter content on soil physical, chemical and biological properties. Int J Plant Anim Environ Sci 4 (4): 245- 252.

Gove L, Nicholson FA, Cook HF, Beck AJ. 2002 Comparison of the effect of surface application and subsurface incorporation of enhanced treated biosolids on the leaching of heavy metals and nutrient through sand and sandy loam soils. Environ Technol 23: 189-198. DOI: $10.1080 / 09593332508618421$

Granatstein DM, Bizdicek, DF, Cochran VL, Gillot LF, Hammel J. 1987. Long Term Tillage and rotation effects on soil microbial biomass, carbon, and Nitrogen. Biol Fertil Soil 5: 265-270. DOI 10.1007/BF00256912

Habig J, Swanepoel C. 2015. Effects of conservation agriculture and fertilization on soil microbial diversity and activity. Environments 2: 358-384. DOI: 10.3390/environments2030358

Hakim NMY, Nyakpa AM, Nugroho LSG, Saul MR..Diha MA, Hong, GB, Baily HH. 2014. Dasar-dasar Ilmu Tanah. Universitas lampung. Bandar Lampung, 1986. Raja Grafindo Persada, Jakarta. [Indonesian].

Hanafiah KA, Napoleon A, Ghofar N. 2003. Biologi Tanah. Ekologi dan Mikrobiologi Tanah [Indonesian].

Hardjowigeno SH. 2015. Ilmu Tanah. Akademikan Pressindo. Jakarta [Indonesian].

Hassink. 1994. Effect of soil texture on the size of the microbial biomass and on the amount of $\mathrm{C}$ and $\mathrm{N}$ mineralized / unit of microbial biomass in Dutch grassland soils. Soil Biol Biochem 26: 1573-1581. DOI: 10.1016/0038-0717(94)90100-7
Jangid K, Williams MA; Franzluebbers AJ, Reeves JH, Jenkins MB Endale DM, Coleman DC, Whitman WB. 2008. Relative impacts of land-use, management intensity and fertilization upon soil microbial community structure in agricultural systems. Soil Biol. Biochem 40: 2843-2853. DOI: 10.1016/j.soilbio.2008.07.030

Knudsen D, Peterson GA, Pratt PF. 1982. Lithium, sodium and potassium. In: Miller, R.H. and Keeney, D.R. Methods of Soil Analysis, Part 2, Chemical and Microbiological Properties. (2 Edn). American Society of Agronomy, Inc., Publisher, Madison, Wisconsin, USA.

Olsen SR, Sommers LE. 1982. Phosphorus. In: Miller R.H, Keeney DR. Methods of Soil Analysis, Part 2, Chemical and Microbiological Properties. (2 Edn). American Society of Agronomy, Inc., Publisher, Madison, Wisconsin, USA.

Papadopoulos A, Bird NRA, Whitmore AP, Mooney SJ. 2006. The effects of organic farming on the soil physical environment. Aspect Appl Biol 79: 263-267.

Serangmo. 2015. Kajian beberapa sifat fisik tanah vertisol dan alfisol akibat pemberian tiga macam bahan dasar pupuk orga-dec serta hasil baby buncis. Buletin Leguminosae 12 (2): 34-40. [Indonesian]

Soetedjo INP 2018. Use of active powder to improve carrying capacity vertisol an alfisol on dryland farming system. Proceeding of the International Conference on Food, Agriculture and Natural Resources (FANRes). DOI: 10.2991/fanres-18-2018.28

Soetedjo INP. 2008. Study The Use of Straw Paddy as Mulch to Improve Water Use Efficiency and Soil Nutrients Content. J Dryland Farm Syst 16: 31-38

Wild A. 1993. Soils and the Environment. An Introduction. Cambridge University Press, Cambridge, UK. 